\title{
Pharmacological Investigations in Traditional Utilization of Alhagi maurorum Medik. in Saharan Algeria: In Vitro Study of Anti-Inflammatory and Antihyperglycemic Activities of Water-Soluble Polysaccharides Extracted from the Seeds
}

\author{
Fatma Zohra Chakou ${ }^{1,2}$, Zakaria Boual ${ }^{1}$, , Mohamed Didi Ould El Hadj ${ }^{1}$, Hakim Belkhalfa ${ }^{3}$, \\ Khaldoun Bachari ${ }^{3}$, Zainab El Alaoui-Talibi ${ }^{4}$, Cherkaoui El Modafar ${ }^{4}$, Farah Hadjkacem ${ }^{1,5}$, Imen Fendri ${ }^{6}(\mathbb{D}$, \\ Slim Abdelkafi ${ }^{5}{ }^{\circ}$, Mounir Traïkia ${ }^{7}$, Didier Le Cerf ${ }^{8}{ }^{\circ}$, Pascal Dubessay ${ }^{2}$, Cédric Delattre ${ }^{2}{ }^{\circledR}$, \\ Guillaume Pierre ${ }^{2}(1)$ and Philippe Michaud ${ }^{2, *(1)}$
}

Citation: Chakou, F.Z.; Boual, Z.; Hadj, M.D.O.E.; Belkhalfa, H.; Bachari, K.; El Alaoui-Talibi, Z.; El Modafar, C.; Hadjkacem, F.; Fendri, I.; Abdelkafi, S.; et al. Pharmacological Investigations in Traditional Utilization of Alhagi maurorum Medik. in Saharan Algeria: In Vitro Study of Anti-Inflammatory and Antihyperglycemic Activities of Water-Soluble Polysaccharides Extracted from the Seeds. Plants 2021, 10, 2658. https://doi.org/10.3390/ plants10122658

Academic Editors: Alessandra Braca and Marinella De Leo

Received: 11 November 2021 Accepted: 1 December 2021 Published: 3 December 2021

Publisher's Note: MDPI stays neutral with regard to jurisdictional claims in published maps and institutional affiliations.

Copyright: (C) 2021 by the authors Licensee MDPI, Basel, Switzerland. This article is an open access article distributed under the terms and conditions of the Creative Commons Attribution (CC BY) license (https:/ / creativecommons.org/licenses/by/ $4.0 /)$.
1 Laboratory for the Protection of Ecosystems in Arid and Semi-Arid Zones, Kasdi Merbah-University, Ouargla 30000, Algeria; fatmazohra.chakou@gmail.com (F.Z.C.); biozakaria1983@gmail.com (Z.B.); mohameddidi@yahoo.fr (M.D.O.E.H.); hadjkacemfarah@gmail.com (F.H.)

2 Institut Pascal, Université Clermont Auvergne, CNRS, Clermont Auvergne INP, 63000 Clermont-Ferrand, France; pascal.dubessay@uca.fr (P.D.); cedric.delattre@uca.fr (C.D.); guillaume.pierre@uca.fr (G.P.)

3 Scientific and Technical Research Center in Physicochemical Analysis, Tipaza 42000, Algeria; hakimbelkhalfa@gmail.com (H.B.); bachari2000@yahoo.fr (K.B.)

4 Faculty of Sciences and Techniques, University of Cadi Ayyad, Marrakech 40000, Morocco; zainab.elalaouitalibi@gmail.com (Z.E.A.-T.); elmodafar@uca.ac.ma (C.E.M.)

5 Laboratory of Enzymatic Engineering and Microbiology, Algae Biotechnology Team, National Engineering School of Sfax, Sfax University, Sfax 3038, Tunisia; slim.abdelkafi@enis.tn

6 Laboratory of Plant Biotechnologies Applied to the Improvement of Plants, Faculty of Sciences, Sfax University, Sfax 3038, Tunisia; imen.fendri@fss.usf.tn

7 Institut de Chimie de Clermont-Ferrand, Université Clermont Auvergne, CNRS, SIGMA Clermont, 63000 Clermont-Ferrand, France; mounir.traikia@uca.fr

8 Département de Chimie, Université de Rouen Normandie, INSA Rouen, CNRS, PBS, 76000 Rouen, France; didier.lecerf@univ-rouen.fr

* Correspondence: philippe.michaud@uca.fr; Tel.: +33-(0)-473-407-422; Fax: +33-(0)-473-407-829

\begin{abstract}
The anti-inflammatory and antihyperglycemic effects of polysaccharides extracted from Alhagi maurorum Medik. seeds, spontaneous shrub collected in Southern of Algerian Sahara were investigated. Their water extraction followed by alcoholic precipitation was conducted to obtain two water-soluble polysaccharides extracts (WSPAM1 and WSPAM2). They were characterized using Fourier transform infrared, ${ }^{1} \mathrm{H} /{ }^{13} \mathrm{C}$ Nuclear Magnetic Resonance, Gas ChromatographyMass Spectrometry and Size Exclusion Chromatography coupled with Multi-Angle Light Scattering. The capacity of those fractions to inhibit $\alpha$-amylase activity and thermally induced Bovine Serum Albumin denaturation were also investigated. WSPAM1 and WSPAM2 were galactomannans with a mannose/galactose ratio of 2.2 and 2.4, respectively. The SEC-MALLS analysis revealed that WSPAM1 had a molecular weight of $1.4 \times 10^{6} \mathrm{Da}$. The investigations highlighted antinflammatory and antihyperglycemic effects in a dose-dependant manner of WSPAM1 and WSPAM2.
\end{abstract}

Keywords: Alhagi; Sahara; polysaccharides; galactomannan

\section{Introduction}

Natural polysaccharides possess chemical structures, making them a key source of lead compounds for management of critical diseases such as diabetes and inflammations [1]. They are also effective ways to prevent low side effects of currently available synthetic drugs e.g., acarbose, miglitol, and voglibose for treatment of diabetes and have noticeable healthy effects on hypoglycemia and gastrointestinal troubles [2-4]. They have 
demonstrated anti-inflammatory effects such as steroid and non-steroid drugs used to treat osteoporosis, hypertension, and cushing syndromes of the former and immunosuppression [5]. Thus, polysaccharides could be the next future alternate anti-diabetic [6-8] and anti-inflammatory [1,9] agents. The mechanisms involved in antidiabetic activity are numerous. They comprise the protection of pancreatic islets from harm by scavenging the free radicals and repairing destroyed $\beta$-cells [10]. They can also improve insulin secretion capacity of pancreatic $\beta$-cells [11]. The viscosity of polysaccharides can inhibit glucose diffusion $[12,13]$ maintaining low levels of glucose concentration in the small intestine [12,14]. They are inhibitors of $\alpha$-D-glucosidases in the bowel, resulting in reduction of carbohydrates' decomposition and absorption [15-17]. Plant-derived polysaccharides have shown their anti-inflammatory activities through the modulation of inflammatory mediators and several immune cells [18]. They ameliorate the dysregulation of pro/anti-inflammatory cytokines [19]. They suppress the release of nitric oxide, Tumor Necrosis Factor-alpha and the expression of inducible nitric oxide synthase [20].

Alhagi maurorum (Fabaceae) is a spiny up shrub [21], native to South East Europe, North Africa, the Middle East and [22]. It has numerous appellations such as Shprim, Shook, Aqool, Lehlah and Shooq El Jamal [23], and therapeutic properties e.g., to remove kidney stones, ureter relaxer, as laxative, diaphoretic, diuretic and expectorant agent [24] Regarding the literature, numerous phytochemical constituents have been identified from the plant such as glycosides, flavonoïds, alkaloïds, saponins, tannins and steroïds, followed by multiple pharmacological activities as antibacterial, anti-inflammatory, antipyretic, analgesic, anti-oxidant and diuretic ones [25].

To our knowledge, no study deals with the pharmacological potentials and chemical elucidation of water-soluble polysaccharides from Alhagi maurorum Medik. seeds.

\section{Materials and Methods}

\subsection{Plant Material}

Alhagi maurorum Medik. (Conservatoire et Jardin botaniques de la Ville de Genève and South African National Biodiversity Institute, Pretoria; Tela Botanica number: 61615), was harvested in August 2019 in Belbachir city for GPS coordinates $26^{\circ} 28^{\prime}$ north latitude and $8^{\circ} 28^{\prime}$ east longitudes of Illizi area (Southern of Algerian Sahara). The plant seeds were obtained manually from cloves previously dried at room temperature for two weeks. They were conserved in Kraft paper and preserved for further research.

\subsection{Extraction and Purification of Polysaccharides}

Two polysaccharide fractions were obtained from the water extraction of the plant seeds to confirm the monosaccharide composition of seed coats mucilage and endosperm cell walls. Firstly, $60.17 \mathrm{~g}$ of crushed material seeds were depigmented and defatted with acetone $96 \%$ under stirring for $14 \mathrm{~h}$ at $27^{\circ} \mathrm{C}$, then filtrated and replaced by ethanol $96 \%$ under reflux for $2 \mathrm{~h}$ and agitation at $80^{\circ} \mathrm{C}$. After filtration through a sintered glass filter of porosity $1(100-160 \mu \mathrm{m})$, pellets were macerated three times in ultrapure water $(1 / 10 ; w / w)$ under reflux and agitation $\left(80^{\circ} \mathrm{C}, 2 \mathrm{~h}\right)$. The mixture was centrifuged $(20,000 \times g ; 20 \mathrm{~min}$; $20^{\circ} \mathrm{C}$ ) and the supernatant filtered under vacuum through a sintered glass filter of porosity $1(100-160 \mu \mathrm{m})$. The filtrate was concentrated to a small volume under reducing pressure using a rotary evaporator followed by alcohol precipitation by three volumes of cold isopropanol $96 \%$ for overnight $\left(-20^{\circ} \mathrm{C}\right)$. After centrifugation $\left(12,000 \times g, 20 \mathrm{~min}, 20^{\circ} \mathrm{C}\right)$, the pellets were dissolved again in ultrapure water and supplemented by three volumes of isopropanol $(96 \%)$ for $24 \mathrm{~h}$ at $-20^{\circ} \mathrm{C}$. Thus, the precipitate containing polysaccharides extract was recovered by centrifugation $\left(12,000 \times g, 20 \mathrm{~min}, 20^{\circ} \mathrm{C}\right)$, coded WSPAM1 and dried using a freeze drier.

Secondly, $20 \mathrm{~g}$ of non crushed seeds were extracted in ultrapure water during $2 \mathrm{~h}$ at $40{ }^{\circ} \mathrm{C}$ under stirring, filter, dried at $45{ }^{\circ} \mathrm{C}$, powdered and macerated two times in ultrapure water $(1 / 10 ; w / w)$ under reflux and agitation $\left(80^{\circ} \mathrm{C}, 2 \mathrm{~h}\right)$. The same loop of 
twice alcoholic precipitation, dissolution was performed as described above to obtain the fraction WSPAM2.

\subsection{Biochemical Composition}

The total and neutral sugar contents of WSPAM1 and WSPAM2 were quantified according to phenol-sulfuric acid [26] and resorcinol-sulfuric acid [27] assays, respectively, using glucose as standard [26,27]. Galacturonic acid was used as standard for m-hydroxydiphenyl assay [28] to determine uronic acid content. Phenolic compounds were quantified by the Folin-Ciocalteu method using gallic acid as standard as described by Singleton [29]. Bradford [30] assay was used to measure proteins content with Bovin Serum Albumin (BSA) as standard. Each analysis was done in triplicate, and data are expressed as means $( \pm$ SEM).

\subsection{FT-IR Spectroscopy Analysis}

Characteristic prints of polysaccharides extracts (fifty scans) were recorded at room temperature (reference against air) on a VERTEX 70 FT-IR apparatus equipped with an ATR A225 diamante (Bruker VERTEX 70, Ettlingen, Germany) ranging from 4000 to $400 \mathrm{~cm}^{-1}$. The data were treated using OPUS 7.2 software (Bruker, Ettlingen, Germany).

\subsection{Analysis of Monosaccharide Composition Using GC/MS-EI}

Ten $\mathrm{mg}$ of each polysaccharide were hydrolyzed with $1 \mathrm{~mL}$ of TFA $2 \mathrm{M}$ at $120{ }^{\circ} \mathrm{C}$ during $90 \mathrm{~min}$, then evaporated under dryness using nitrogen stream at $60{ }^{\circ} \mathrm{C}$. Derivatization of monosaccharides was realized according to Pierre et al. [31,32], dissolving the lyophilizate in pyridine and Sylon (BSTFA/TMCS; 99\%/1\%). The mix was incubated at room temperature $2 \mathrm{~h}$ and under Argon to form trimethylsilyl-O-glycosides which were solubilized in dichloromethane after evaporation of reagent. The samples were injected on an Agilent 6890 Series GC System coupled to an Agilent 5973 Network, equipped with an OPTIMA-1MS column (Macherey-Nagel; $30 \mathrm{~m}, 0.32 \mathrm{~mm}, 0.25 \mu \mathrm{m}$ ) from Macherey-Nagel with a helium flow rate of $2.3 \mathrm{~mL} / \mathrm{min}$. The first time, temperature was at $100{ }^{\circ} \mathrm{C}$ for $3 \mathrm{~min}$. In a second step an increment of $8{ }^{\circ} \mathrm{C} / \mathrm{min}$ up to $200{ }^{\circ} \mathrm{C}$ for $1 \mathrm{~min}$ was applied before a final increment of $5{ }^{\circ} \mathrm{C} / \mathrm{min}$ up to $250^{\circ} \mathrm{C}$. Electronic Impact $(\mathrm{EI}, 70 \mathrm{eV})$ ionization method was performed with the trap temperature set at $150{ }^{\circ} \mathrm{C}$ and the target ion was fixed at $40-800 \mathrm{~m} / \mathrm{z}$. The relative molar proportions were calculated using area normalization method. As monosaccharides standards, Ara, Rha, Gal, Glc, Xyl, Man, GlcA and GalA were prepared and analyzed following the same procedure.

\subsection{Polysaccharide Hydrolysis}

One $\mathrm{g}$ of WSPAM1 was hydrolyzed in $100 \mathrm{~mL}$ of $20 \% \mathrm{H}_{2} \mathrm{SO}_{4}$ at $50{ }^{\circ} \mathrm{C}$ during $30 \mathrm{~min}$ with stirring. The hydrolysate was neutralized with $10 \mathrm{M} \mathrm{NaOH}$ and then dialyzed $(3.5 \mathrm{kDa})$ against ultrapure water for $72 \mathrm{~h}$ before being freeze-dried and coded HPAM.

\subsection{NMR Analysis}

WSPAM1 was dissolved at $100 \mathrm{~g} / \mathrm{L}$ in $\mathrm{D}_{2} \mathrm{O}(99.9 \% \mathrm{D})$ and freeze-dried (three times). Before analysis, WSPAM was dissolved in $\mathrm{D}_{2} \mathrm{O}(100 \mathrm{~g} / \mathrm{L})$. The ${ }^{1} \mathrm{H}$ NMR spectra were obtained at $353 \mathrm{~K}$ on a Bruker AVANCE III HD $500 \mathrm{MHz}$ spectrometer equipped with Bruker $5 \mathrm{~mm}$ inverse probe TXI $\left({ }^{1} \mathrm{H} /{ }^{13} \mathrm{C} /{ }^{15} \mathrm{~N}\right)$ with z-gradient coil probe. For all samples, a one-dimensional spectrum $\left({ }^{1} \mathrm{H}\right.$ NMR) was acquired using a $\mathrm{ZG}$ sequence. 128 scans were collected with an $90^{\circ}$ impulsion time of $9.7 \mu$ s at a power of $14 \mathrm{~W}$, a 4 s relaxation time, an acquisition of $3.3 \mathrm{~s}$, a spectral window of $20 \mathrm{ppm}$ and $65 \mathrm{~K}$ data points zero-filled to $131 \mathrm{~K}$ before Fourier transformation with $0.3 \mathrm{~Hz}$ line broadening. The ${ }^{13} \mathrm{C}$ NMR spectra were registered at $353 \mathrm{~K}$ on the same spectrometer as ${ }^{1} \mathrm{H}$ spectra. Dimensional ${ }^{13} \mathrm{C}$ NMR spectra were acquired using a ZGPG sequence (WALTZ16 power gated decoupling with a $80 \mu \mathrm{s}$ at $0.2 \mathrm{~W}) .20,000$ scans were collected with an $90^{\circ}$ impulsion time of $12 \mu$ s at a power of $190 \mathrm{~W}$, 
a $2 \mathrm{~s}$ relaxation time, an acquisition of $1.20 \mathrm{~s}$, a spectral window of $220 \mathrm{ppm}$ and $65 \mathrm{~K}$ data points zero-filled to $131 \mathrm{~K}$ before Fourier transformation with $3 \mathrm{~Hz}$ line broadening.

\subsection{Molecular Weight}

High pressure size exclusion chromatography (HPSEC) equipped with on line three detectors, a He-Ne laser at 690 nm (HELEOS II, Wyatt Technology Corp, Santa Barbara, CA, USA), a multi-angle laser light scattering (MALLS) filled with a K5 cell (50 L), a differential refractive index (RID 10A, Shimadzu, Japan) and a viscosimeter (Viscostar II, Wyatt Technology Corp., USA) was carried out to study the molecular weight and homogeneity of polysaccharide extract, measuring parameters such as the weight average molecular weight $\left(\mathrm{M}_{\mathrm{w}}\right)$, the number-average molecular weight $\left(\mathrm{M}_{\mathrm{n}}\right)$ and the polydispersity index $\left(Đ=\mathrm{M}_{\mathrm{w}} / \mathrm{M}_{\mathrm{n}}\right)$ of WSPAM1. Two columns (OHPAK SB-G guard column, OHPAK SB806 and $804 \mathrm{HQ}$ columns (Shodex)) were eluted with $\mathrm{LiNO}_{3} 0.1 \mathrm{M}$ at $0.5 \mathrm{~mL} / \mathrm{min}$. WSPAM1 was solubilized at $1 \mathrm{~g} / \mathrm{L}$ in $\mathrm{LiNO}_{3} 0.1 \mathrm{M}$ during $48 \mathrm{~h}$ at room temperature under stirring, and the solution was filtered through a $0.45 \mu \mathrm{m}$ filter before injection through a $500 \mu \mathrm{L}$ full loop.

\subsection{Biological Properties of Polysaccharides Extracts}

\subsubsection{Albumin Denaturation Inhibitory Activity}

The anti-inflammatory test was carried out following Osman et al. [33] and Bakka et al. [34] with some modifications, to test their ability to inhibit the thermally denaturation of BSA. The polysaccharides extracts and Ibuprofen (control positive) were prepared at concentrations of $0.1,0.2,0.4,0.8$ and $1 \%(w / v)$. The react mixture contained $0.45 \mathrm{~mL}$ of BSA $0.5 \%(w / v)$, $0.05 \mathrm{~mL}$ of polysaccharide or Ibuprofen concentrations, excepted the negative control. The sample was incubated at $37^{\circ} \mathrm{C}$ for $20 \mathrm{~min}$ and then heated at $70^{\circ} \mathrm{C}$ for $10 \mathrm{~min}$. After cooling, $2.5 \mathrm{~mL}$ of Phosphate Buffer Solution ( $\mathrm{pH} 7.4$ ) was added to the reaction mixture before measuring $\mathrm{A}_{660}$. The inhibition of albumin denaturation was calculated following Equation (1). The tests were carried out in triplicate.

$$
\text { Inhibition }(\%)=\left(1-\frac{D}{C}\right) \times 100
$$

$D \mathrm{~A}_{660}$ of the test sample

$C \mathrm{~A}_{660}$ of negative control (reading without inhibitor)

\subsubsection{Antihyperglycemic Activity}

The control of glucose production following the consumption of food sources, such as $\alpha$-amylase inhibitors, might be a good approach for the management of type 2 diabetes as well as hyperglycemia $[35,36]$, in which WSPAM1, WSPAM2 and HPAM were investigated by evaluating inhibition of $\alpha$-amylase activity as described by Kumar et al. [37] and Kajaria et al. [38], using their methods with minor modifications. Sixty $\mu \mathrm{L}$ of different aqueous solutions $(1.25,2.5,3.75,5,6.25,7.5,8.75$ and $10 \mathrm{mg} / \mathrm{mL})$ of polysaccharide and acarbose (positive control) or ultrapure water (negative control) were mixed with $30 \mu \mathrm{L}$ of $\alpha$-amylase from human suffered of pancreatitis (5 IU/L) and incubated at $37^{\circ} \mathrm{C}$ during $15 \mathrm{~min}$. Subsequently, $150 \mu \mathrm{L}(0.5 \mathrm{mg} / \mathrm{mL})$ of 2 -chloro- $p$-nitrophenyl- $\alpha$-D-maltotrioside (CNPG3) used as substrate was added under stirring. Inhibition releasing of 2-chloro- $p$ nitrophenol measured polysaccharide's ability to inhibit $\alpha$-amylase activity measuring $\mathrm{A}_{405}$ and expressed according to Equation (2). The tests were carried out in triplicate.

$$
\text { Inhibition }(\%)=\left(\text { Control }_{\text {test }}-\text { Test }_{\text {sample }} / \text { Control }_{\text {test }}\right) \times 100
$$




\subsection{Statistical Analysis}

The results data were treated via Statistical Package for Social Science (SPSS) version 16 and Microsoft Excel 2007 for scheming graphs. The correlation between parameters was determined by Student's $t$-test for conditions to use are $p$-value less than chosen significance level $\alpha=0.05$.

\section{Results and Discussion}

\subsection{Biochemical Characterization}

The isolated polysaccharides from A. maurorum Medik. seeds were amorphous white powders with a cream tint. The extraction yields of WSPAM1 and WSPAM2 were, respectively, $12.58 \%$ and $9.83 \%(w / w)$, which was higher than yields polysaccharides found from other seeds species of Alhagi genus, Alhagi pseudalhagi (MB) Desv. at 2.8\% [39] and 4\% of Alhagi persarum Boiss [40]. The biochemical analysis (Table 1) of WSPAM1 and WSPAM2 showed a similar biochemical composition. The polysaccharides extracts WSPAM1 and WSPAM2 were mainly composed of neutral sugars with values of 58.98 and $53.1 \%(w / w)$ respectively and low uronic acid contents with values of 12.76 and $13.75 \%(w / w)$, respectively. As well, both fractions are lightly contaminated by phenolic compounds $(7.57 \%$ and $9.21 \% w / w)$ and very low protein contents $(2.32 \%$ and $1.6 \% w / w)$ were measured. WSPAM1 was then chosen for structural investigations.

Table 1. Biochemical characterization of polysaccharides from A. maurorum Medik. seeds.

\begin{tabular}{|c|c|c|c|c|c|}
\hline & \multicolumn{3}{|c|}{ Carbohydrate Composition ( $w / w \%)$} & \multirow{2}{*}{$\begin{array}{c}\text { Phenolic } \\
\text { Compounds } \\
(w / w \%)\end{array}$} & \multirow{2}{*}{$\begin{array}{l}\text { Proteins } \\
(w / w \%)\end{array}$} \\
\hline & Total & Neutral & Uronic Acids & & \\
\hline WSPAM1 & $49.21 \pm 0.037$ & $58.98 \pm 0.02$ & $12.76 \pm 0.029$ & $7.57 \pm 2 \times 10^{-5}$ & $2.32 \pm 10^{-3}$ \\
\hline WSPAM2 & $43.95 \pm 0.026$ & $53.1 \pm 0.009$ & $13.75 \pm 0.005$ & $9.21 \pm 0.5 \times 10^{-5}$ & $1.6 \pm 5 \times 10^{-4}$ \\
\hline
\end{tabular}

\subsection{Structural Characterization}

\subsubsection{FT-IR Spectroscopy}

The infrared spectrum of WSPAM1 is represented in Figure 1. Characteristic bands of polysaccharides were attributed between 527 and $3351 \mathrm{~cm}^{-1}$. The intense peak at $3351.04 \mathrm{~cm}^{-1}$ corresponded to O-H stretching vibration from polysaccharide and water whereas the signal attributed at $2929.26 \mathrm{~cm}^{-1}$ was assigned to aliphatic bending groups $(\mathrm{C}-\mathrm{H})$ [41]. The vibration of carboxylate groups $(\mathrm{C}=\mathrm{O})$ were also observed at $1636.30 \mathrm{~cm}^{-1}$ [42]. The signals from 1222.10 to $1547.70 \mathrm{~cm}^{-1}$ were assigned to $\mathrm{C}-\mathrm{H}$ deformation vibrations and rotational vibrations of $\mathrm{C}-\mathrm{OH}$ groups [43].

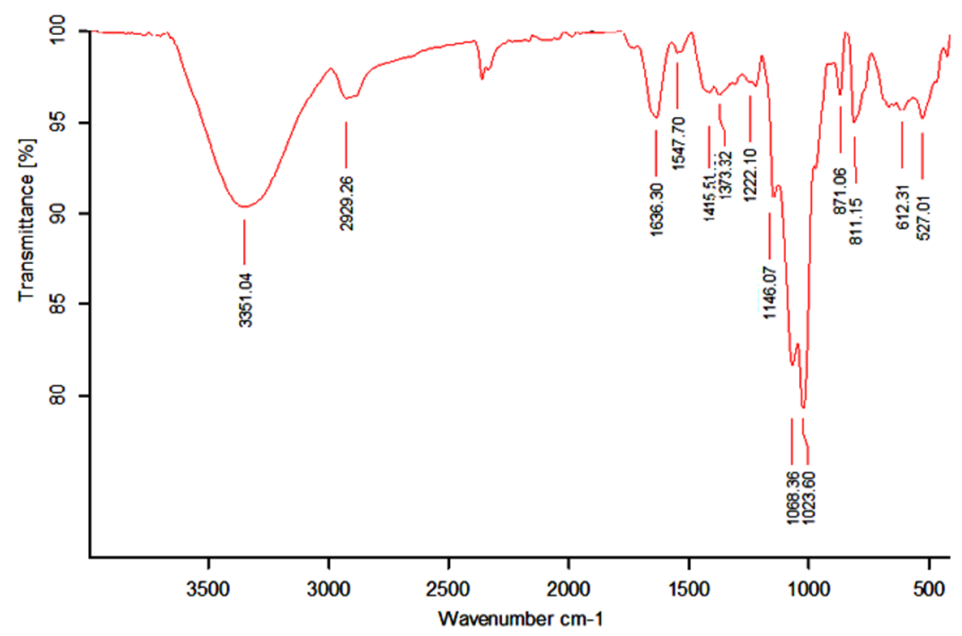

Figure 1. FT-IR spectrum of WSPAM1. 
The main peak at $1146.07 \mathrm{~cm}^{-1}$ was attributed to C-O functions of carbohydrates [44] while the two bands at 1023.60 and $1068.36 \mathrm{~cm}^{-1}$ suggested a pyranose form for carbohydrates constituting WSPAM1 [45]. The absorption bands at $871.06 \mathrm{~cm}^{-1}$ and $811.15 \mathrm{~cm}^{-1}$ were attributed, respectively, to $\alpha$-glycosides linkages [46] and $\alpha$-D-galactopyranose residue [47].

\subsubsection{GC-MS/EI}

As illustrated in Figure 2, GC-MS/EI analysis indicates that polysaccharide extracts WSPAM1 (a) and WSPAM2 (b) were exclusively composed of galactose and mannose with a ratio of Mannose/Galactose equal to 2.22 and 2.44, respectively. The pyranose form of monosaccharides was confirmed according to Harris et al. [48] with the estimation of the abundance of $204 / 217$ ratio $(m / z)$. These results suggested a galactomannan type polysaccharide and confirm the similarities of WSPAM1 and WSPAM2 compositions. These ratios were close to that reported for polysaccharides extracted from the seeds of Leguminosae [49], A. persarum Boiss (2.00) [40] and Sonoran mezquite (2.05) [50]. Kodiralieva and Rakhmanberdyeva [39] reported a lower $M / G$ ratio of 0.5 for the polysaccharide extracted from A. pseudalhagi (MB) Desv seeds. However, the galactomannan nature of this polysaccharide should be questioned as authors identified significant amounts of other monosaccharides in its composition such as arabinose, xylose and rhamnose.

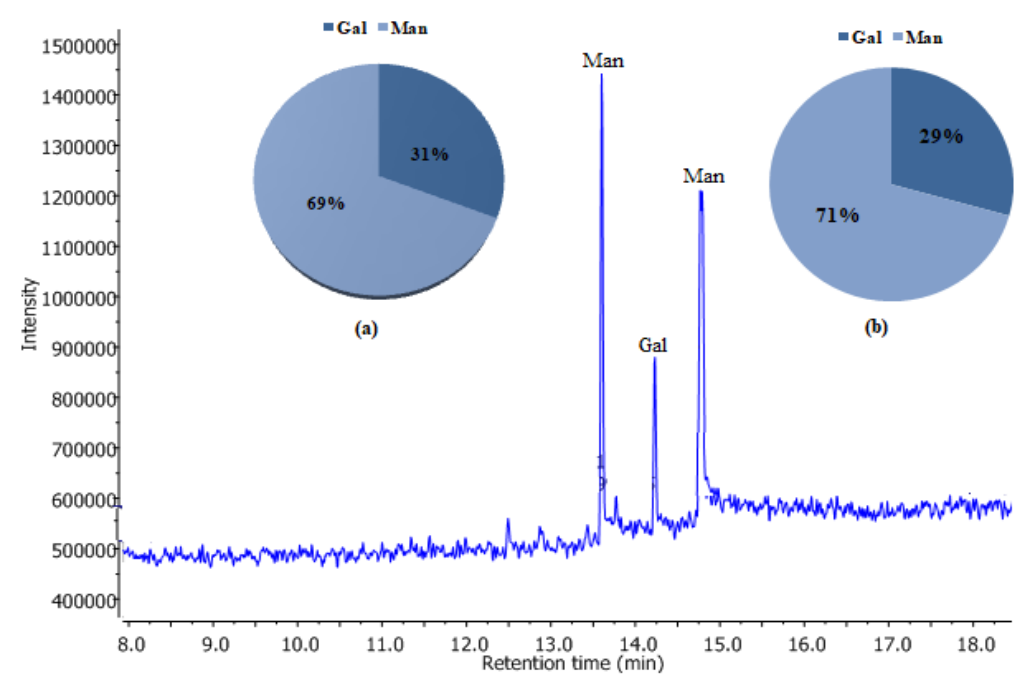

Figure 2. Monosaccharide compositions of WSPAM1 (a) and WSPAM2 (b) using GC-MS/EI.

\subsection{3. ${ }^{1} \mathrm{H},{ }^{13} \mathrm{C}$ NMR and HSQC Analysis}

The polysaccharide obtained from Alhagi maurorum (WSPAM1) was analyzed by ${ }^{13} \mathrm{C}$ and ${ }^{1} \mathrm{H}$ NMR spectroscopy. Analysis of the polysaccharide revealed specific carbohydrates signals of galactomannans confirming the monosaccharidic composition (Figure 3 and Table 2).

${ }^{1} \mathrm{H}$ NMR spectrum showed two distinct signals at 5.51 and 5.23 ppm attributed to anomeric protons $\mathrm{H}-1$ of $\alpha$-D-galactopyranose (G1) and H-1 of $\beta$-D-mannopyranose (M1/M1'), respectively. The molar ratio of $\mathrm{M} / \mathrm{G}$ calculated from the integrations of the relative peak areas of these two signals was 1.96. This value was coherent with that obtained after GC-MS analysis $(\mathrm{M} / \mathrm{G}=2.22)$.

As shown in ${ }^{13} \mathrm{C}$ NMR spectrum (Figure $3 \mathrm{~b}$ ), the anomeric signal at $99.51 \mathrm{ppm}$ and 100.67 ppm was assigned to C-1 of $\alpha$-D-galactopyranose and unsubstituted $\beta$-Dmannopyranose residues, respectively. Moreover, signals observed at $61.85 \mathrm{ppm}, 61.29 \mathrm{ppm}$ and 67.27 ppm were attributed to C-6 of $\alpha$-D-galactopyranose (G6), C-6 of an unsubstituted $\beta$-D-mannopyranose (M6) and C-6 of a substituted $\beta$-D-mannopyranose (M'6) in the same order. 
(a)

(b)
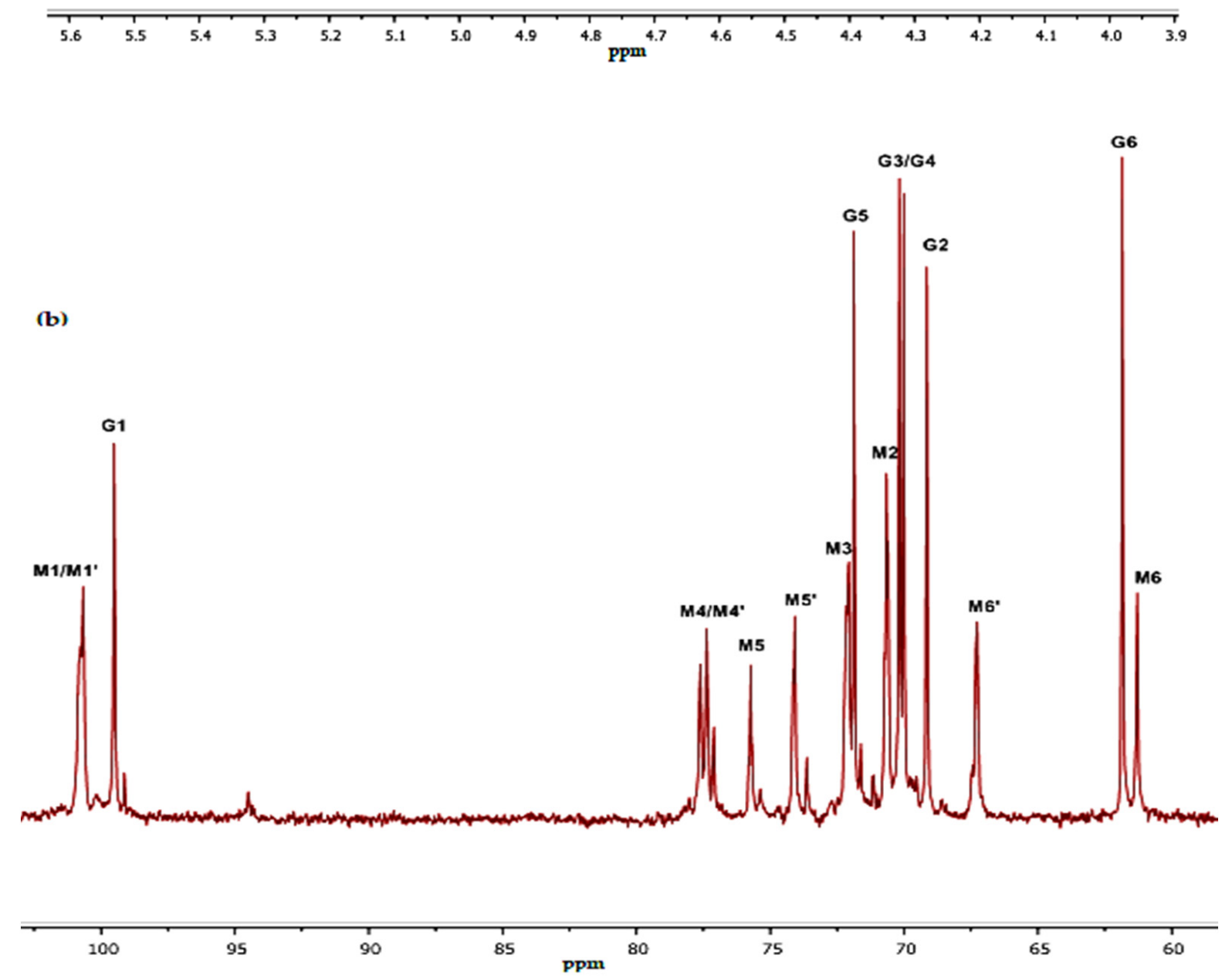

Figure 3. Spectra ${ }^{1} \mathrm{H}$ NMR (a) and ${ }^{13} \mathrm{C}$ NMR (b) of WSPAM1 from Alhagi maurorum Medik. seeds. G: $\alpha$-D-galactopyranose; M: $\beta$-D-mannopyranose non substituted; $M^{\prime}: \beta$-D-mannopyranose substituted at O-6 position. 
Table 2. Assignments of ${ }^{1} \mathrm{H} /{ }^{13} \mathrm{C}$ NMR signals of Alhagi maurorum seeds galactomannan.

\begin{tabular}{ccccccc}
\hline & \multicolumn{5}{c}{ Chemical Shifts (ppm) } \\
\hline Type of Unit & H/C-1 & H/C-2 & H/C-3 & H/C-4 & H/C-5 & H/C-6 \\
\hline$\alpha$-D-galactopyranosyl (G) & $5.51 / 99.51$ & $4.32 / 69.15$ & $4.41 / 70.17$ & $4.50 / 70.01$ & $4.39 / 71.87$ & $4.25 / 61.85$ \\
$\beta$-D-mannopyranosyl unsubstituted (M) & $5.23 / 100.67$ & $4.61 / 70.66$ & $4.30 / 72.16$ & $4.31 / 77.34$ & $4.03 / 75.73$ & $4.38 / 61.29$ \\
\hline$\beta$-D-mannopyranosyl substituted (M') & $5.23 / 100.77$ & $4.61 / 70.66$ & $4.30 / 72.16$ & $4.36 / 77.50$ & $4.22 / 74.08$ & $4.31 / 67.27$ \\
\hline
\end{tabular}

Compared to other galactomannans extracted from the seeds of different leguminous plants, M/G ratio of WSPAM1 was slightly elevate to those estimated for Astragalus gombo Bunge, Sesbania virgata and Leucaena leucocephala to 1.7, 1.5 and 1.6, respectively [50-53]. The purity of galactomannan and the M/G ratios of seeds from Fabaceae was related to plant origin and extraction processes $[40,53,54]$.

\subsubsection{Molecular Weight}

The molecular weight $\left(\mathrm{M}_{\mathrm{w}} \mathrm{g} / \mathrm{mol}\right)$, molecular weight distribution $\left(\mathrm{M}_{\mathrm{n}} \mathrm{g} / \mathrm{mol}\right)$ and intrinsic viscosity [ $\eta$ ] of WSPAM1 extracted from the seeds of A. maurorum Medik. were determined using Size Exclusion Chromatography coupled with Multi-Angle Light Scattering (SEC-MALLS) (Table 3). The $\mathrm{M}_{\mathrm{w}}$ and $\mathrm{M}_{\mathrm{n}}$ were $1.40 \times 10^{6}$ and $2.7 \times 10^{5} \mathrm{~g} / \mathrm{mol}$, respectively. These values were elevated but coherent compared to other galactomannans reported in literature. As an example, the galactomannan obtained from Astragalus gombo Bunge seeds had a Mw of $1.1 \times 10^{6}$ and a Mn of $0.82 \times 10^{5} \mathrm{~g} / \mathrm{mol}$ [51]. Moreover, Mw of galactomannans from Delonix regia and Caesalpinia gilliesii were, respectively, $7.23 \times 10^{5}$ and $1.17 \times 10^{5} \mathrm{~g} / \mathrm{mol}[55,56]$. It is well recognized that the molecular weight of galactomannans can be highly diversified depending on parameters such as their geographical and origins botanical, the fractionation and extraction conditions (e.g., $\mathrm{pH}$, temperature, type of organic solvents used for aggregation) and the extent of the galactosyl substitution or depolymerization [57].

Table 3. Physicochemical analysis of WSPAM.

\begin{tabular}{ccccc}
\hline $\mathbf{M}_{\mathrm{w}}(\mathrm{g} / \mathrm{mol})$ & $\mathbf{M}_{\mathbf{n}}(\mathrm{g} / \mathbf{m o l})$ & $\begin{array}{c}\text { Polydispersity } \\
\text { Index }(Đ)\end{array}$ & $\begin{array}{c}\text { Intrinsic Viscosity } \\
{[\mathbf{\eta}](\mathbf{m L} / \mathbf{g})}\end{array}$ & $\mathbf{R}_{\mathbf{h}}(\mathbf{n m})$ \\
\hline $1.40 \times 10^{6}$ & $2.7 \times 10^{5}$ & 5.2 & 970 & 57.3 \\
\hline
\end{tabular}

The hydrodynamic radius $\left(R_{h}\right)$ of $57.3 \mathrm{~nm}$ and the elevated polydispersity index of $\mathrm{Đ}=5.2$ indicated the high degree of polydispersity of WSPAM1, higher to those reported for several leguminous species in the range of 1.23 to $2.79[55,56,58,59]$. The intrinsic viscosity

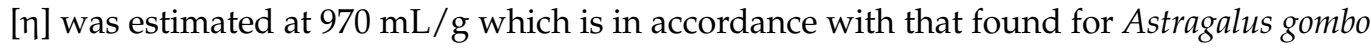
Bunge galactomannan $(860 \mathrm{~mL} / \mathrm{g})$ [51].

\subsection{Biological Activities}

\subsubsection{Inhibition of BSA Denaturation}

Inflammation is the body's first immune system response to an infection, stress and damage. Continuous inflammation has a close relationship to many diseases, such as arthritis, atherosclerosis and cancer [18]. Regarding the literature, protein denaturation caused by some lysosomal enzymes released during the inflammation $[33,60]$, is one of the biggest causes of biological loss of protein function [61]. The capacity of WSPAM1 and WSPAM2 on inhibition of BSA against heat denaturation temperature at $70{ }^{\circ} \mathrm{C}$ is shown in Figure 4. WSPAM1 has shown a higher inhibitory effect (14.89-86.23\%) than the standard drug (Ibuprofen) (22.78-79.46\%) at same concentrations from 1 to $10 \mathrm{mg} / \mathrm{mL}$ and $\mathrm{IC}_{50}$ values of $5.8 \mathrm{mg} / \mathrm{mL}$ and $6.29 \mathrm{mg} / \mathrm{mL}$, respectively. However, a lower inhibitory activity was observed for WSPAM2 (2.59-26.42\%), which was 3 times lower than other fractions at the same concentration range. This lower activity highlights the importance 
of the depigmented and defatted steps before the extraction of galactomannan from the seeds of A. maurorum Medik. Indeed, Ibanoglu (2005) reported that the augmentation in the enthalpy of denaturation of BSA in the presence of hydrocolloids was recognized to protect globular proteins against aggregation through blockage of their hydrophobic binding sites by the bulky polysaccharide moiety [62]. In addition, it is known that the biological activities of polysaccharides are markedly influenced by their molecular weights, monosaccharide compositions, glycosidic bond types and non sugar contents [63].

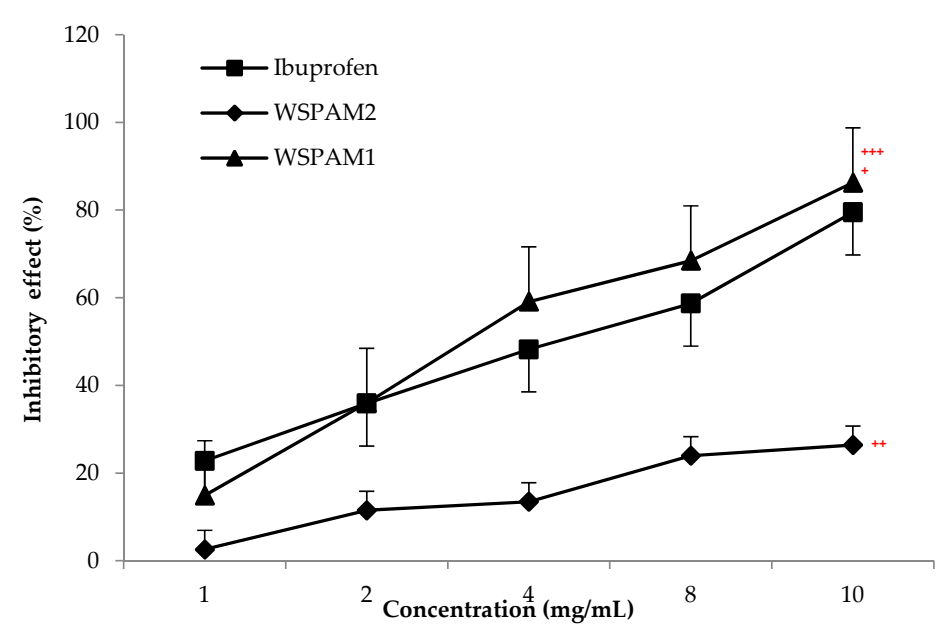

Figure 4. Inhibitory effects of WSPAM1, WSPAM2 and Ibuprofen on BSA thermally denaturation. ${ }^{+} p>0.1$ and $^{++} p<0.01$ compared to Ibuprofen. Correlation between the inhibitory effect of polysaccharide extracts and the molecular weight was expressed with ${ }^{+++} p<0.001$.

\subsubsection{Antihyperglycemic Activity}

In vitro antihyperglycemic effects of polysaccharide extracts of $A$. maurorum Medik. seeds were quantified and compared to acarbose as positive control measuring inhibition of $\alpha$-amylase activity (Figure 5).

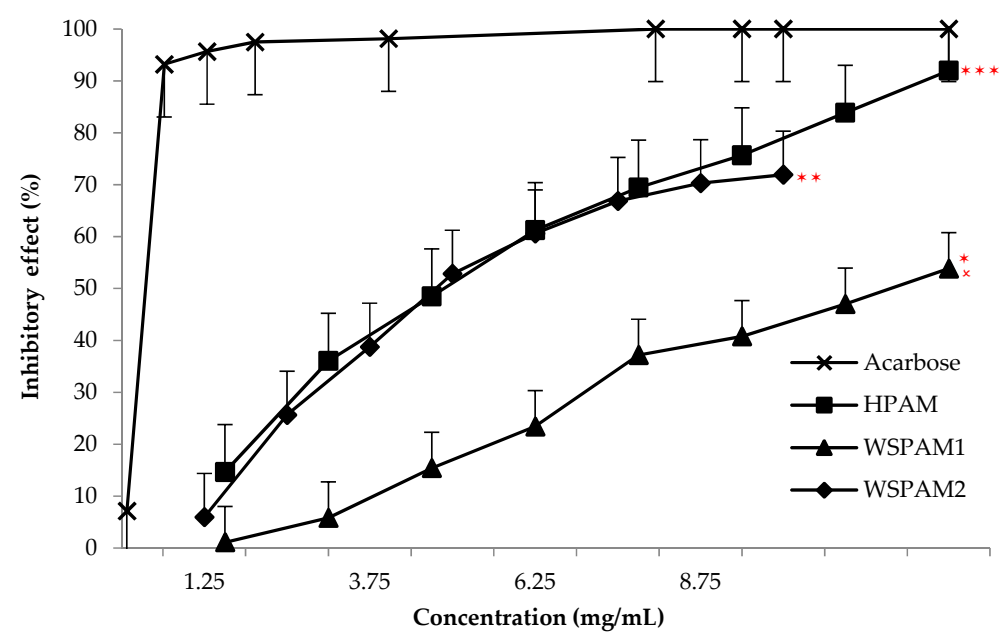

Figure 5. Antihyperglycemic activity of polysaccharide extracts of A. maurorum Medik. seeds on inhibition of $\alpha$-amylase enzyme activity. ${ }^{*} p<0.001,{ }^{* *} p<0.05,{ }^{* * *} p<0.1$ compared with acarbose (positive control) as well as to to molecular weight $\left({ }^{*} p<0.0001\right)$.

The results showed that the hydrolyzate HPAM $(p<0.1)$ and WSPAM2 $(p<0.05)$ significantly $(p<0.0001)$ have a strong inhibitory effect on $\alpha$-amylase activity to 91.96 and $71.92 \%$ at $10 \mathrm{mg} / \mathrm{mL}$ with an $\mathrm{IC}_{50}$ values of $5.43 \mathrm{mg} / \mathrm{mL}$ and $6.81 \mathrm{mg} / \mathrm{mL}$, respectively (Table 4). While a moderate significant inhibitory potential was attributed to WSPAM1 
$(p<0.001)$ with a value of $53.83 \%\left(\mathrm{IC}_{50}=9.28 \mathrm{mg} / \mathrm{mL}\right)$ compared to $100 \%$ from acarbose to $6.45 \mathrm{mg} / \mathrm{mL}$ used of the drug.

Table 4. The median concentrations (IC50) of A. maurorum polysaccharides on inhibition of $\alpha-$ amylase activity.

\begin{tabular}{ccccc}
\hline & WSPAM1 & WSPAM2 & HPAM & Acarbose \\
\hline $\mathrm{IC} 50(\mathrm{mg} / \mathrm{mL})$ & 9.28 & 6.81 & 5.43 & 6.45 \\
\hline
\end{tabular}

The inhibitory effects of polysaccharides extracted from the plant seeds were considerably better than other plants tested for their hypoglycemic activity and highly significantly correlated to the molecular weight $(p<0.0001)$. Indeed, according to Kabat and Bezer [64] most polysaccharides with medicinal properties were high molecules with molecular weights above $100 \mathrm{kDa}$. In addition, authors [16] reported a good inhibitory effect of $\alpha$-glucosidase by a polysaccharide (APS) extract from dried Radix Astragali having a high molecular weight (693 kDa). Other polysaccharides obtained from Cucurbita moschata inhibited $41.3 \%$ of $\alpha$-amylase activity at a concentration of $5 \mathrm{mg} / \mathrm{mL}$ [35]. A galactomannan extracted from the endosperm of Adenanthera pavonina's L. seeds (GAP) exhibited after 30 days of treatment, at $1 \%$ and $2 \%$, a significant glycemia decrease in comparison to diabetic control on streptozotocin induced diabetic mice [65]. In addition, galactomannan obtained from Arenga Pinnata Merr. significantly reduced blood glucose after $90 \mathrm{~min}$ treatment without any side effect [66]. Studies report that viscosity and concentration of polysaccharides contribute directly to their hypoglycemic effects because they limit digestive enzymatic activity and glucose absorption in the gut $[67,68]$.

\section{Conclusions}

The structural characterization and in vitro biological investigations of water-soluble polysaccharides extracted from $A$. maurorum Medik. seeds revealed a galactomannan of high molecular weight close to $1.40 \times 10^{6} \mathrm{~g} / \mathrm{mol}$ with polydispersity value of 5.2. WSPAM1 had a significant inhibitory effect on BSA thermally denaturation with an $\mathrm{IC}_{50}=5.8 \mathrm{mg} / \mathrm{mL}$. Moreover, HPAM (hydrolyzed fraction) exhibited the strongest inhibitory $\alpha$-amylase activity of $91.96 \%\left(\mathrm{IC}_{50}=5.3 \mathrm{mg} / \mathrm{mL}\right)$. Both in vitro studies of biological activities of WSPAM1 were correlated significantly to their molecular weights. Further in vivo and in vitro studies will be carried out to understand the specific inhibitory mechanisms of antihyperglycemic effects of polysaccharides extracted from the seeds of Alhagi maurorum Medik.

Author Contributions: Conceptualization, F.Z.C., P.M., Z.B.; methodology, F.Z.C., P.M., Z.B.; validation, P.M., Z.B.; formal analysis, F.Z.C., D.L.C.; investigation, P.M., Z.B., H.B., K.B., Z.E.A.-T., F.H., I.F., M.T., D.L.C.; Resources, C.D.; writing—original draft preparation, F.Z.C., P.M., Z.B., P.D.; writing-review and editing, F.Z.C., P.M., Z.B., M.D.O.E.H., C.E.M., S.A.; supervision, P.M., Z.B.; project administration, P.M., Z.B., G.P.; funding acquisition, Z.B., P.M., G.P. All authors have read and agreed to the published version of the manuscript.

Funding: This work was funded by the FRENCH MINISTRY OF EUROPE AND FOREIGN AFFAIRS AND THE ALGERIAN, MOROCCAN, AND TUNISIAN MINISTRIES OF HIGHER EDUCATION AND SCIENTIFIC RESEARCH, within the framework of the HUBERT CURIEN PROGRAM (PHC Maghreb), grant number 18MAG36.

Institutional Review Board Statement: Not applicable.

Informed Consent Statement: Not applicable.

Data Availability Statement: Raw data are available on request from the corresponding author.

Conflicts of Interest: No conflict of interest to declare. 


\section{References}

1. Aswad, M.; Rayan, M.; Abu-Lafi, S.; Falah, M.; Raiyn, J.; Abdallah, Z.; Rayan, A. Nature is the best source of anti-inflammatory drugs: Indexing natural products for their anti-inflammatory bioactivity. Inflamm. Res. 2018, 67, 67-75. [CrossRef]

2. Chakrabarti, R.; Singh, B.; Vanchhawng, L.; Thirumurugan, K. Screening of nine herbal plants for in vitro a-amylase inhibition. Screening 2014, 7, 84-89.

3. Liyanagamage, D.S.N.K.; Jayasinghe, S.; Attanayake, A.P.; Karunaratne, V. Medicinal plants in management of diabetes mellitus: An overview. Ceylon J. Sci. 2020, 49, 3-11. [CrossRef]

4. Sukalingam, K.; Ganesan, K.; Ponnusamy, K. Evaluation of antidiabetic activity of polyherbal formulations on type 2 diabetic patients: A single blinded randomized study. Int. J. Intg. Med. Sci. 2015, 2, 90-98. [CrossRef]

5. Ma, L.; Liu, T.W.; Wallig, M.A.; Dobrucki, I.T.; Dobrucki, L.W.; Nelson, E.R.; Swanson, K.S.; Smith, A.M. Efficient targeting of adipose tissue macrophages in obesity with polysaccharide nanocarriers. ACS Nano 2016, 10, 6952-6962. [CrossRef]

6. Zhou, J.; Xu, G.; Yan, J.; Li, K.; Bai, Z.; Cheng, W.; Huang, K. Rehmannia glutinosa (Gaertn.) DC. polysaccharide ameliorates hyperglycemia, hyperlipemia and vascular inflammation in streptozotocin-induced diabetic mice. J. Ethnopharm. 2015, 164, 229-238. [CrossRef]

7. Ma, H.T.; Hsieh, J.F.; Chen, S.T. Anti-diabetic effects of Ganoderma lucidum. Phytochemistry 2015, 114, 109-113. [CrossRef] [PubMed]

8. Tang, S.M.; Yang, Z.M.; Chen, W.Q.; Yuan, Q.F.; Chen, S.Y.; Li, H.Z. Astragalus polysaccharide improves type 2 diabetes mellitus in rats by protecting islet $\beta$ cells. Acad. J. Second Mil. Med. Univ. 2017, 38, 482-487.

9. Wang, Y.H.; Zeng, K.W. Natural products as a crucial source of anti-inflammatory drugs: Recent trends and advancements. Tradit. Med. Res. 2019, 4, 257-268. [CrossRef]

10. Li, Y.G.; Ji, D.F.; Zhong, S.; Lv, Z.Q.; Lin, T.B.; Chen, S.; Hu, G.Y. Hybrid of 1-deoxynojirimycin and polysaccharide from mulberry leaves treat diabetes mellitus by activating PDX-1/insulin-1 signaling pathway and regulating the expression of glucokinase, phosphoenolpyruvate carboxykinase and glucose-6-phosphatase in alloxan-induced diabetic mice. J. Ethnopharmacol. 2011, 134, 961-970. [CrossRef]

11. Zhang, Y.; Ren, C.; Lu, G.; Mu, Z.; Cui, W.; Gao, H.; Wang, Y. Anti-diabetic effect of mulberry leaf polysaccharide by inhibiting pancreatic islet cell apoptosis and ameliorating insulin secretory capacity in diabetic rats. Int. Immunopharmacol. 2014, 22, 248-257. [CrossRef] [PubMed]

12. Chung, W.S.F.; Meijerink, M.; Zeuner, B.; Holck, J.; Louis, P.; Meyer, A.S.; Wells, J.M.; Flint, H.J.; Duncan, S.H. Prebiotic potential of pectin and pectic oligosaccharides to promote antiinflammatory commensal bacteria in the human colon. FEMS Microbiol. Ecol. 2017, 93, 127. [CrossRef]

13. Hu, J.L.; Nie, S.P.; Xie, M.Y. Antidiabetic mechanism of dietary polysaccharides based on their gastrointestinal functions. J. Agric. Food Chem. 2018, 66, 4781-4786. [CrossRef]

14. Kameyama, K.; Itoh, K. Intestinal colonization by a Lachnospiraceae bacterium contributes to the development of diabetes in obese mice. Microbes Environ. 2014, 29, 427-430. [CrossRef]

15. Zhang, Z.; Kong, F.; Ni, H.; Mo, Z.; Wan, J.B.; Hua, D.; Yan, C. Structural characterization, $\alpha$-glucosidase inhibitory and DPPH scavenging activities of polysaccharides from guava. Carbohydr. Polym. 2016, 144, 106-114. [CrossRef] [PubMed]

16. Zhu, Z.Y.; Luo, Y.; Dong, G.L.; Ren, Y.Y.; Chen, L.J.; Guo, M.Z.; Wang, X.T.; Yang, X.Y.; Zhang, Y. Effects of the ultra-high pressure on structure and $\alpha$-glucosidase inhibition of polysaccharide from Astragalus. Int. J. Biol. Macromol. 2016, 87, 570-576. [CrossRef] [PubMed]

17. Zhang, S.; Li, X.Z. Inhibition of $\alpha$-glucosidase by polysaccharides from the fruit hull of Camellia oleifera Abel. Carbohydr. Polym. 2015, 115, 38-43. [CrossRef]

18. Hou, C.; Chen, L.; Yang, L.; Ji, X. An insight into anti-inflammatory effects of natural polysaccharides. Int. J. Biol. Macromol. 2020, 153, 248-255. [CrossRef]

19. Wang, Y.; Zhang, N.; Kan, J.; Zhang, X.; Wu, X.; Sun, R.; Tang, S.; Liu, J.; Qian, C.; Jin, C. Structural characterization of water-soluble polysaccharide from Arctium lappa and its effects on colitis mice. Carbohydr. Polym. 2019, 213, 89-99. [CrossRef]

20. Cuia, C.; Chen, S.; Wang, X.; Yuan, G.W.; Jiang, F.; Chen, X.Y.; Wang, L. Characterization of Moringa oleifera roots polysaccharide MRP-1 with anti-inflammatory effect. Int. J. Biol. Macromol. 2019, 32, 844-851. [CrossRef]

21. Suthar, P.; Mathur, K.; Goyal, M.; Yadav, S.K. Traditional uses, phytochemistry, pharmacological properties of plant Alhagi maurorum (Medik.). Rev. World J. Pharm. Pharmac. Sci. 2016, 5, 682-692.

22. International Union for Conservation of Nature and Natural Resources. A Guide to Medicinal Plants in North Africa; IUCN Publications Services Unit: Malaga, Spain, 2005; p. 91.

23. Al-Snafi, A.E. Alhagi maurorum as a potential medicinal herb: An Overview. Int. J. Pharm. Rev. Res. 2015, 5, 130-136.

24. Marashdah, M.S.; Farraj, A.I. Pharmacological activity of $2 \%$ aqueous acetic acid extract of Alhagi maurorum roots. J. Saudi Chem. Soc. 2010, 14, 247-250. [CrossRef]

25. Al-Snafi, A.E.; Al-Kamel, M.L.; Esmael, M.E. Antifungal effect of Alhagi maurorum phenolic extract. IOSR J. Pharm. 2019, 9, 7-14.

26. Dubois, M.; Gilles, K.A.; Hamilton, J.K.; Rebers, P.T.; Smith, F. Colorimetric method for determination of sugars and related substances. Anal. Chem. 1956, 28, 350-356. [CrossRef]

27. Monsigny, M.; Petit, C.; Roche, A.C. Colorimetric determination of neutral sugars by a resorcinol sulfuric acid micromethod. Anal. Biochem. 1988, 175, 525-530. [CrossRef] 
28. Blumenkrantz, N.; Asboe-Hansen, G. New method for quantitative determination of uronic acids. Anal. Biochem. 1973, 54, 484-489. [CrossRef]

29. Singleton, V.L.; Rossi, J.A. Colorimetry of total phenolics with phosphomolybdic-phosphotungstic acid reagents. Am. J. Enol. Vitic. 1965, 16, 144-158.

30. Bradford, M.M. A rapid and sensitive method for the quantitation of microgram quantities of protein utilizing the principle of protein-dye binding. Anal. Biochem. 1976, 72, 248-254. [CrossRef]

31. Pierre, G.; Graber, M.; Rafiliposon, B.A.; Dupuy, C.; Orvain, F.; de Crignis, M.; Maugard, T. Biochemical composition and changes of extracellular polysaccharides (ECPS) produced during microphytobenthic biofilm development (Marennes-Oléron, France). Microb. Ecol. 2012, 63, 157-169. [CrossRef]

32. Pierre, G.; Zhao, J.M.; Orvain, F.; Dupuy, C.; Klein, G.L.; Graber, M.; Maugard, T. Seasonal dynamics of extracellular polymeric substances (EPS) in surface sediments of a diatom-dominated intertidal mudflat (Marennes-Oléron, France). J. Sea Res. 2014, 92, 26-35. [CrossRef]

33. Osman, N.I.; Sidik, N.J.; Awal, A.; Adam, N.A.M.; Rezali, N.I. In vitro xanthine oxidase and albumin denaturation inhibition assay of Barringtonia racemosa L. and total phenolic content analysis for potential anti-inflammatory use in gouty arthritis. J. Intercult. Ethnopharmacol. 2016, 5, 344-345. [CrossRef] [PubMed]

34. Bakka, C.; Smara, O.; Hadjadj, M.; Dendougui, H.; Mahdjar, S.; Benzid, A. In vitro Anti-inflammatory activity of Pistacia atlantica Desf. extracts. Asian J. Res. Chem. 2019, 12, 322-325. [CrossRef]

35. Wang, L.; Liu, F.; Wang, A.; Yu, Z.; Xu, Y.; Yang, Y. Purification, characterization and bioactivity determination of a novel polysaccharide from pumpkin (Cucurbita moschata) seeds. Food Hydrocol. 2017, 66, 357-364. [CrossRef]

36. Chen, C.; You, L.J.; Abbasi, A.M.; Fu, X.; Liu, R.H.; Li, C. Characterization of polysaccharide fractions in mulberry fruit and assessment of their antioxidant and hypoglycemic activities in vitro. Food Funct. 2016, 7, 530-539. [CrossRef]

37. Kumar, A.; Lakshman, K.; Jayaveera, K.; Shekar, S.; Swamy, N.; Khan, S.; Velumurga, C. In vitro $\alpha$-amylase inhibition and antioxidant activities of methanolic extract of Amaranthus caudatus Linn. Oman Med. J. 2011, 26, 166-170. [CrossRef]

38. Kajaria, D.; Tripathi, J.; Tripathi, Y.B.; Tiwari, S. In-vitro $\alpha$-amylase and glycosidase inhibitory effect of ethanolic extract of antiasthmatic drug-Shirishadi. J. Adv. Pharm. Technol. Res. 2013, 4, 206-209. [CrossRef]

39. Kodiralieva, F.A.; Rakhmanberdyeva, R.K. Polysaccharides from seeds of plants of the family Fabaceae. Chem. Nat. Compd. 2011, 47, 268-269. [CrossRef]

40. Rakhimov, D.A.; Dzhumamuratova, A. Polysaccharides of Alhagi persarum. Chem. Nat. Compd. 1993, 29, 674-675. [CrossRef]

41. Rjeibi, I.; Hentati, F.; Feriani, A.; Hfaiedh, N.; Delattre, C.; Michaud, P.; Pierre, G. Novel antioxidant, anti- $\alpha$-amylase, antiinflammatory and antinociceptive water-soluble polysaccharides from the aerial part of Nitraria retusa. Foods 2020, 9, 28. [CrossRef]

42. Lukova, P.; Nikolova, M.; Petit, E.; Elboutachfaiti, R.; Vasileva, T.; Katsarov, P.; Manev, H.; Gardarin, C.; Pierre, G.; Michaud, P.; et al. Prebiotic activity of poly-and oligosaccharides obtained from Plantago major L. leaves. Appl. Sci. 2020, 10, 2648. [CrossRef]

43. Chouana, T. Caractérisation Structurale et Activités Biologiques Des Polysaccharides D'Astragalus Gombo Bunge. Ph.D. Thesis, Université Clermont Auvergne, Clermont Ferrand, France, 2017.

44. Patel, M.K.; Tanna, B.; Mishra, A.; Jha, B. Physicochemical characterization, antioxidant and anti-proliferative activities of polysaccharide extracted from psyllium (P. ovata) leaves. Int. J. Biol. Macromol. 2018, 118, 976-987. [CrossRef]

45. Ren, Y.Y.; Zhu, Z.Y.; Sun, H.Q.; Chen, L.J. Structural characterization and inhibition on $\alpha$-glucosidase activity of acidic polysaccharide from Annona squamosa. Carbohydr. Polym. 2017, 174, 1-12. [CrossRef]

46. Shabani, H.; Askari, G.; Jahanbin, K.; Khodaeian, F. Evaluation of physicochemical characteristics and antioxidant property of Prunus avium gum exudates. Int. J. Biol. Macromol. 2016, 93, 436-441. [CrossRef]

47. Tamaki, Y.; Teruya, T.; Tako, M. The Chemical Structure of Galactomannan Isolated from Seeds of Delonix regia. Biosci. Biotechnol. Biochem. 2010, 74, 1110-1112. [CrossRef] [PubMed]

48. Harris, P.J.; Henry, R.J.; Blakeney, A.B.; Stone, B.A. An improved procedure for the methylation analysis of oligosaccharides and polysaccharides. Carbohydr. Res. 1984, 127, 59-73. [CrossRef]

49. Bento, J.F.; Mazzaro, I.; de Almeida Silva, L.M.; de Azevedo Moreira, R.; Ferreira, M.L.C.; Reicher, F.; de Oliveira Petkowicz, C.L. Diverse patterns of cell wall mannan/galactomannan occurrence in seeds of the Leguminosae. Carbohydr. Polym. 2013, 92, 192-199. [CrossRef] [PubMed]

50. Figueroa, D.B.; López, M.Q.; Durazo, A.R.; Lerma, M.S. Hydrothermal technique for isolation of galactomannan from seeds of Sonoran mezquite (Prosopis spp.). Rev. Mex. Ing. Quimica 2017, 16, 457-465. [CrossRef]

51. Chouana, T.; Pierre, G.; Vial, C.; Gardarin, C.; Wadouachi, A.; Cailleu, D.; Le Cerf, D.; Boual, Z.; El Hadj, M.O.; Michaud, P.; et al. Structural characterization and rheological properties of a galactomannan from Astragalus gombo Bunge seeds harvested in Algerian Sahara. Carbohydr. Polym. 2017, 175, 387-394. [CrossRef]

52. Muschin, T.; Yoshida, T. Structural analysis of galactomannans by NMR spectroscopy. Carbohydr. Polym. 2012, 87, 1893-1898. [CrossRef]

53. Srivastava, M.; Kapoor, V.P. Seed galactomannans: An overview. Chem. Biodivers. 2005, 2, 295-317. [CrossRef]

54. Chaubey, M.; Kapoor, V.P. Structure of a galactomannan from the seeds of Cassia angustifolia Vahl. Carbohydr. Res. 2001, 332, 439-444. [CrossRef] 
55. Nwokocha, L.M.; Williams, P.A.; Yadav, M.P. Physicochemical characterization of the galactomannan from Delonix regia seed. Food Hydrocoll. 2018, 78, 132-139. [CrossRef]

56. Abdel-Megeed, R.M.; Hamed, A.R.; Matloub, A.A.; Kadry, M.O.; Abdel-Hamid, A.H.Z. Regulation of apoptotic and inflammatory signaling pathways in hepatocellular carcinoma via Caesalpinia gilliesii galactomannan. Mol. Cell. Biochem. 2019, 451, 173-184. [CrossRef]

57. Mathur, N.K. Industrial Galactomannan Polysaccharides; Taylor \& Francis Group; CRC Press: Boca Raton, FL, USA, $2012 ;$ p. 187.

58. Fidan, H.; Stankov, S.; Petkova, N.; Petkova, Z.; Iliev, A.; Stoyanova, M.; Ivanova, T.; Zhelyazkov, N.; Ibrahim, S.; Stoyanova, A.; et al. Evaluation of chemical composition, antioxidant potential and functional properties of carob (Ceratonia siliqua L.) seeds. J. Food Sci. Technol. 2020, 57, 2404-2413. [CrossRef]

59. Boual, Z.; Pierre, G.; Delattre, C.; Benaoun, F.; Petit, E.; Gardarin, C.; Michaud, P.; Ould El Hadj, M.D. Mediterranean semi-arid plant Astragalus armatus as a source of bioactive galactomannan. Bioact. Carbohydr. Diet. Fibre 2015, 5, 10-18. [CrossRef]

60. Rani, A.A.; Punitha, S.M.J.; Rema, M. Anti-inflammatory activity of flower extract of Cassia auriculata-an in-vitro study. Int. Res. J. Pharm. Appl. Sci. 2014, 4, 57-60.

61. Anoop, M.V.; Bindu, A.R. In-vitro anti-inflammatory activity studies on Syzygium zeylanicum (L) DC leaves. Int. J. Pharma. Res. Rev. 2015, 4, 18-27.

62. Ibanoglu, E. Effect of hydrocolloids on the thermal denaturation of proteins. Food Chem. 2005, 90, 621-626. [CrossRef]

63. Yang, L.Q.; Zhang, L.M. Chemical structural and chain conformational characterization of some bioactive polysaccharides isolated from natural sources. Carbohydr. Polym. 2009, 76, 349-361. [CrossRef]

64. Kabat, E.A.; Bezer, A.E. The effect of variation in molecular weight on the antigenicity of dextran in man. Biochem. Biophys. 1958, 78, 306-318. [CrossRef]

65. Benjamin, S.; Vieira, I.P.; Mendes, F.P.; Da Silva, S.; Paim, R.T.; Da Silva, B.; Florean, E.O.T.; Guedes, M.F. Antidiabetic effects of galactomannans from Adenanthera pavonina L. in streptozotocin-induced diabetic mice. Asian Pac. J. Trop. Med. 2018, 11, 116. [CrossRef]

66. Tarigan, J.B.; Dalimunthe, A.; Perangin-angin, S. Polysaccharide Extract on Blood Glucose Level. In The Effect of Arenga Pinnata Merr, Proceedings of the International Conference of Science, Technology, Engineering, Environmental and Ramification Researches (ICOSTEERR); Science and Technology Publications: Medan, Indonesia, 2020; pp. 964-968.

67. Srichamroen, A.; Thomson, A.B.R.; Field, C.J.; Basu, T.K. In vitro intestinal glucose uptake is inhibited by galactomannan from Canadian fenugreek seed (Trigonella foenum graecum L.) in genetically lean and obese rats. Nutr. Res. 2009, 29, 49-54. [CrossRef] [PubMed]

68. Jenkins, D.J.; Wolever, T.M.; Nineham, R.; Taylor, R.; Metz, G.L.; Bacon, S.; Hockaday, T.D. Guar crispbread in the diabetic diet. Br. Med. J. 1978, 2, 1744-1746. [CrossRef] 